\title{
D- STATCOM Based Voltage Regulation and Harmonic Damping
}

\author{
D. Kalyankumar \\ Department of Electrical and Electronics Engineering, \\ Saranathan College of Engineering, \\ Trichy, Tamil Nadu, India.
}

\author{
Dr. V. Kirubakaran \\ Asst.Professor, Rural Energy Centre, \\ Ganghigram Rural University, \\ Gandhigram, Tamil Nadu, India.
}

\begin{abstract}
This paper discusses a shunt active filter intended for installation on a power distribution system. The active filter has an additional capability to regulate the distribution line voltage by means of adjusting reactive power. Theoretical analysis investigates the dynamic performance of combined harmonic damping and voltage regulation. As a result, harmonic damping makes it possible to improve the stability of the control loop for voltage regulation, and the combined harmonic damping. The system with control scheme is implemented in Matlab/Simulink. The simulation results are shown to verify the effectiveness of the combined harmonic damping and voltage regulation.
\end{abstract}

Keywords - Distributed generators, Power distribution systems, Shunt active filters, Voltage regulation, Hysteresis current control, D$\mathrm{Q}$ reference frame theory.

\section{INTRODUCTION}

The harmonic problems have been serious in industrial and utility power distribution systems. "Harmonic amplification" is one of the most serious problems. It is caused by harmonic resonance between line inductance and power factor correction (PFC) capacitors installed by consumers. Active filters for damping out harmonic resonance in industrial and utility power distribution systems have been researched [1]-[5].The authors have proposed a voltage detecting shunt active filter for installation on a power distribution system [1]-[2]. The main purpose of installing the active filter is to damp out the harmonic amplification. The active filter is characterized by behaving like a resistor for harmonic frequencies, resulting in damping out the harmonic amplification throughout a distribution line. Since a real distribution system consists of four to eight distribution lines, installing the active filter on the end bus of each line is effective in harmonic damping. On the other hand, distributed generators such as solar cells, wind turbines and soon have been developed and installed on utility power distribution systems. A distributed generator produces an amount of active power, and injects it into the distribution system. The active power influenced by weather and/or wind velocity causes voltage fluctuations in the distribution line, because it changes independently of power demand from loads. Moreover, distributed generators may produce the following problem in a utility distribution system: Some newly developed towns, apartments and buildings are being equipped with solar cells. This may make difficult voltage regulation throughout multiple distribution lines. A static synchronous compensator (STATCOM) is one of the most effective solutions to regulate the line voltage [6]. The STATCOM consists of a voltage source converter connected in shunt with the power system, and enables to control a leading or lagging reactive power by means of adjusting its ac voltage. A STATCOM for installation on a distribution system, or the so - called D-STATCOM, has been researched and put into commission to solve voltage fluctuations and or voltage flickers [6]-[8]. It is possible to use a shunt active filter as a D-STATCOM, because they have the same circuit configuration. However, no literature has addressed the dynamic behavior of the active filter when it performs both harmonic damping and voltage regulation at the same time. This paper discusses a shunt active filter intended for installation on a power distribution system, with focus on voltage regulation capability. Theoretical analysis as well as computer simulation provides the dynamic performance of harmonic damping and voltage regulation. As a result, harmonic damping has the capability to improve the stability of voltage regulation. Thus, adjustment of the feedback gains makes it possible to reduce voltage fluctuation in transient states, when the active filter has the function of combined harmonic damping and voltage regulation. The simulation results are shown to verify the effectiveness of the active filter capable of both harmonic damping and voltage regulation.

\section{ACTIVE FILTER FOR HARMONIC DAMPING \\ 2.1 System Configuration}

Fig. 1 shows a $200 \mathrm{~V}$ simplified power distribution feeder under noload conditions, where a shunt pure active filter for damping out harmonic propagation is connected by a LC filter. The purpose of the capacitor in LC filter is to impose high impedance to the fundamental frequency, so that the fundamental voltage appears exclusively across the capacitor. This means that no fundamental voltage is applied across the active filter [8].

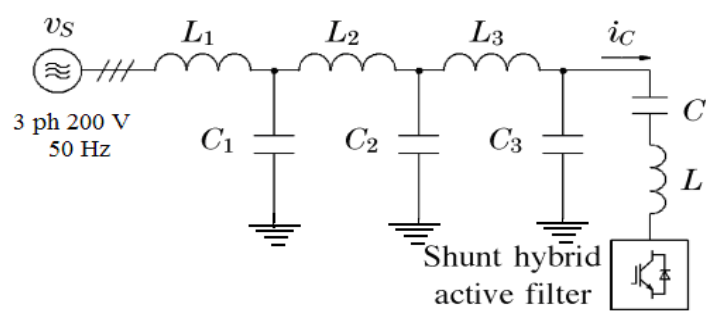

Fig.1. Shunt active filter with LC filter.

Fig.2. shows the detailed power circuit of the active filter, which consists of a three - phase voltage fed PWM inverter and a series connection of $\mathrm{L}$ and $\mathrm{C}$ per phase. Note that the tuned frequency of $\mathrm{L}$ and $\mathrm{C}$ is not the fifth - harmonic frequency but around the seventh harmonic frequency. The reason is that the seventh - tuned LC filter 
is less bulky than the fifth - tuned LC filter as long as both filters have the same inductor as L. The dc-bus of the PWM inverter has only a capacitor without external supply, and the $\mathrm{dc}$ - bus voltage is controlled by the Active filter. The Active filter is controlled so as to draw the compensating current from the distribution line.

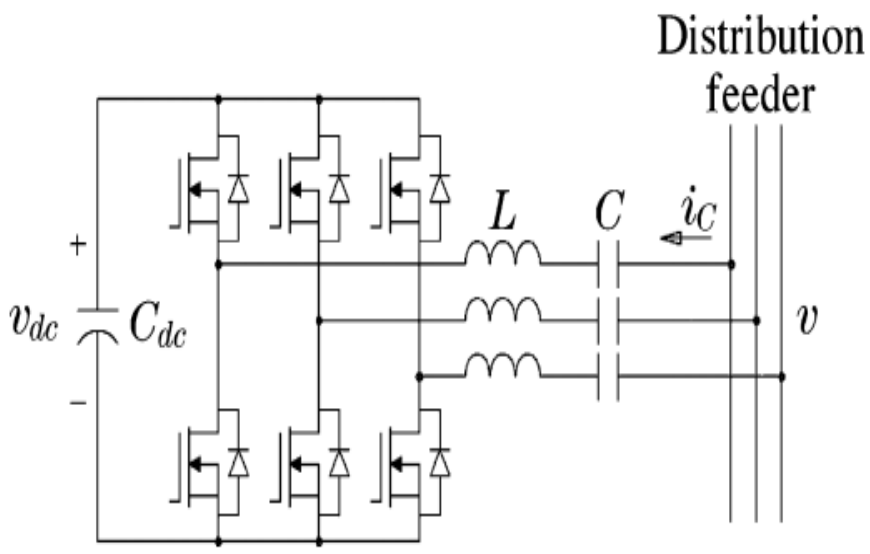

Fig.2. Power circuit of the active filter.

\subsection{Calculation Of Characteristics Impedance}

Fig. 3 shows the simplified circuit of distribution system under no-load conditions. In the feeder simulator harmonic is generated by a non linear load (diode rectifier) connected at bus, which produces an amount of harmonic voltage. When a lossless line is assumed, the characteristic impedance of the feeder simulator, can be calculated as using equation (1)

$$
\mathrm{Z}_{\mathrm{O}}=\sqrt{\frac{L}{C}}=0.8 \Omega
$$

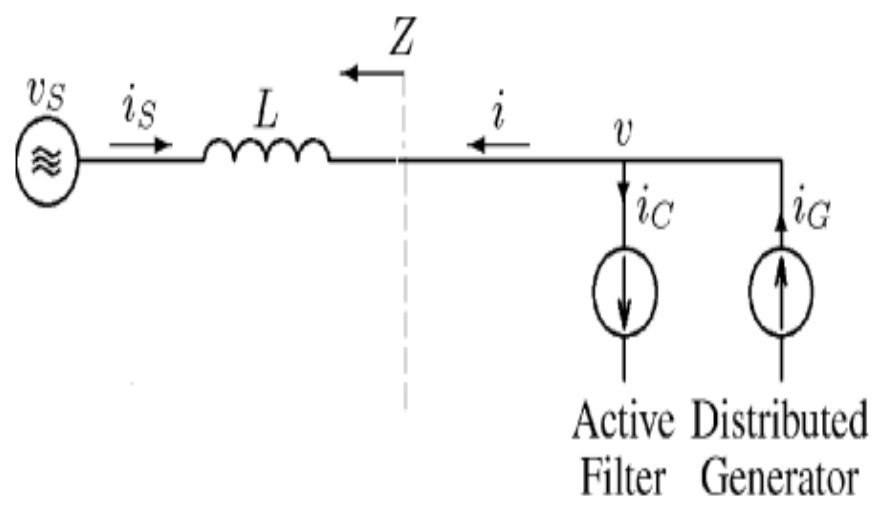

Fig. 3. Simplified circuit of the distribution system.

\subsection{Operating principle}

The hybrid filter with current control is based on voltage detection. The compensating current of the active filter consists of a fundamental component and harmonic components. The fundamental component is determined by the impedance of the LC filter while the harmonic components are controlled by the active filter. Three-phase voltages and currents are detected at the installation bus. The harmonic voltage in each phase is extracted from the detected three phase voltage, and then the harmonic voltage is amplified by a control gain $\mathrm{K}_{\mathrm{V}}$. Thus the harmonic current reference $\mathrm{I}^{*}$ ch is given by equation (2),

$$
i^{*}{ }^{c h}=K_{\mathrm{V}} * V_{\mathrm{h}}
$$

The actual harmonic compensating current is extracted from the detected compensating current. Assuming that is equal to its reference, the hybrid filter behaves as a damping resistor of $1 / \mathrm{K}_{\mathrm{V}}$ [V/A] for harmonic frequencies. The optimal value of is equal to the inverse of the characteristic impedance of the distribution feeder. With this value, the hybrid filter can damp out harmonic propagation effectively.

\section{CONTROL SCHEMES}

\subsection{Harmonic Damping}

There are several methods to extract the harmonic components from the detected three-phase waveforms. Among them, the so-called $\mathrm{p}-\mathrm{q}$ theory based on time domain has been widely applied to the harmonic extraction circuit of active filters. The detected three-phase voltage is transformed into the D - Q0 coordinates as shown in Fig.4. Two first order digital high pass filters (HPFs) with the same cut off frequency as $20 \mathrm{~Hz}$ extract the dc component $\mathrm{Vhd}^{*}$, Vhq* and V0 which corresponds to the fundamental frequency in the coordinates [7].

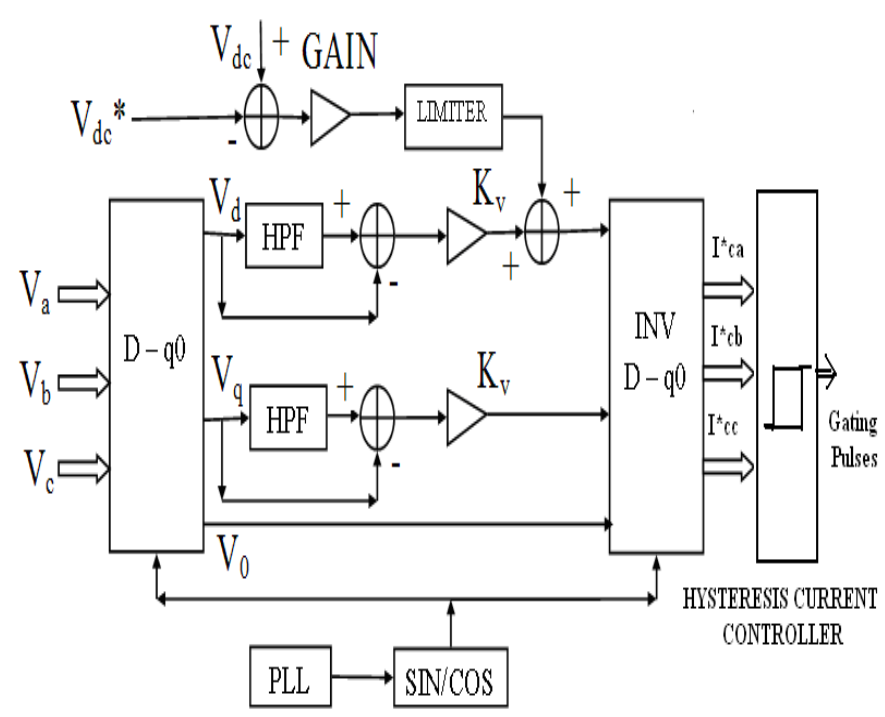

Fig.4. Block diagram of the control circuit equipped with the function of voltage regulation and harmonic damping.

\subsection{Voltage Detection}

In line - voltage regulation part is performed by a feedback control. Two co - ordinates $\mathrm{V}_{\mathrm{d}}$ and $\mathrm{V}_{\mathrm{q}}$ is compared with harmonic extracted voltage $\mathrm{V}_{\mathrm{hd}}{ }^{*}$ and $\mathrm{V}_{\mathrm{hq}}{ }^{*}$. A gain $\mathrm{K}_{\mathrm{V}}$ amplifies and to produce current references for harmonic damping $\mathrm{I}_{\mathrm{hd}}, \mathrm{I}_{\mathrm{hq}}$, and $\mathrm{I}_{0}$ as shown in equation (3), equation (4) and equation (5). The current reference for the voltage - source inverter is the sum of the current references from the three parts, as follows: 


$$
\begin{aligned}
& \mathrm{I}_{\mathrm{cd}}^{*}(\mathrm{~s})=\mathrm{K}_{\mathrm{v}}\left(\mathrm{G}_{\mathrm{h}} \mathrm{V}_{\mathrm{hd}}{ }^{*}-\mathrm{V}_{\mathrm{d}}\right)+\left(\mathrm{V}_{\mathrm{dc}} *-\mathrm{V}_{\mathrm{dc}}\right) \\
& \mathrm{I}_{\mathrm{cq}}^{*}(\mathrm{~s})=\mathrm{K}_{\mathrm{v}}\left(\mathrm{G}_{\mathrm{h}} \mathrm{V}_{\mathrm{hq}}{ }^{*}-\mathrm{V}_{\mathrm{q}}\right) \\
& \mathrm{I}_{0}^{*}(\mathrm{~s})=1 / 3\left(\mathrm{~V}_{\mathrm{a}}+\mathrm{V}_{\mathrm{b}}+\mathrm{V}_{\mathrm{c}}\right)
\end{aligned}
$$

The obtained current reference is converted three phase current reference by inverse $\mathrm{D}-\mathrm{Q}$ transformation $\mathrm{I}_{\mathrm{ca}}{ }_{\mathrm{c}}, \mathrm{I}_{\mathrm{cb}}^{*}$, and $\mathrm{I}_{\mathrm{cc}}{ }_{\mathrm{c}}$. The three three phase reference compensating current is compared with the active filter compensating current extracted from ac system. Thus three phase compensating current $\mathrm{I}_{\mathrm{ca}}, \mathrm{I}_{\mathrm{cb}}$, and $\mathrm{I}_{\mathrm{cc}}$ are produced. The obtained reference current is given to a hysteresis current controller in order to generate controlled gate signal for shunt active filter.

\subsection{DC - Bus Voltage Control and PWM Method}

A critical issue in this hybrid active filter is the dc-bus voltage control. The dc bus consists of a single capacitor charged from the power supply. During operation, the active filter may absorb an amount of active power into, or release it from, the dc capacitor. Excessive active power absorption will increase the dc-bus voltage, and may damage the active filter. The strategy used to control the dcbus voltage is based on active power control. According to the D- Q theory, a dc component in the $\mathrm{D}-\mathrm{Q}$ coordinates corresponds to active power. No direct axis current on the $\mathrm{D}-\mathrm{Q}$ coordinates flows in the $\mathrm{LC}$ filter. Thus, the active power is controlled by adjusting the quadrature axis component. The direct axis is set to zero. Fig. 4 shows a block diagram for the dc bus voltage control. The dc-bus voltage is detected and compared with a reference, amplifying the error signal by a control gain of 0.12. A limiter is included in the dc-bus control loop. It is designed to ensure a smooth transient response and to avoid sudden increments or decrements in the dc-bus voltage. It is also designed to prevent the control loop from numerical saturation in the control signals. The limiter is set to $\pm 2.5 \mathrm{~V}$ in the digital controller which corresponds to $25 \%$ of the maximum control signal. For a 40-V dc-bus voltage, the maximum dc-bus control signal corresponds to a $\pm 10 \mathrm{~V}$ peak-to-peak fundamental voltage for the inverter. The pulse width modulation (PWM) gate pulses for DSTATCOM are generated by using hysteresis current control method as in Fig. 4 [6]-[8].

\section{Simulation Study}

Table 1 shows the circuit parameters used in the D-STATCOM (shunt active filter). The simulation is carried for distribution system with and without shunt active filter. Total harmonic distortion is calculated for the system voltage and current. Tables 2 show the THD for with and without shunt active filter. From the Table 2, THD for with shunt active filter is very low compared to without filter. In Fig. 5 show the three phase voltages of distribution system without shunt active filter. It can be seen that the harmonic is disturbed in voltages. In Fig. 6 show the three phase voltages of distribution system with shunt active filter. It could be found that the wave shapes of the voltages are pure sinusoidal form.

Table 1. Circuit parameters used for the shunt active filter (DSTATCOM).

\begin{tabular}{|c|c|c|}
\hline Source voltage & $\mathrm{V}_{\mathrm{a}}=\mathrm{V}_{\mathrm{b}}=\mathrm{V}_{\mathrm{c}}$ & $200 \mathrm{~V}$ \\
\hline Power & $\mathrm{P}$ & $20 \mathrm{KVA}$ \\
\hline Frequency & $\mathrm{F}$ & $50 \mathrm{~Hz}$ \\
\hline Line inductance & $\mathrm{L}_{\mathrm{a}}=\mathrm{L}_{\mathrm{b}}=\mathrm{L}_{\mathrm{c}}$ & 22.7 \\
\hline
\end{tabular}

\begin{tabular}{|c|c|c|}
\hline & & $\mathrm{mH}$ \\
\hline DC - Capacitor & $\mathrm{C}$ & $4700 \mu \mathrm{F}$ \\
\hline DC - voltage & $\mathrm{V}_{\mathrm{dc} \text { ref }}$ & $40 \mathrm{~V}$ \\
\hline
\end{tabular}

Table 2. Total harmonic distortion (THD).

\begin{tabular}{|c|c|c|c|c|c|c|}
\hline \multirow{2}{*}{ Parameters } & \multicolumn{3}{|c|}{ Source current Is } & \multicolumn{3}{c|}{ Voltage V } \\
\cline { 2 - 7 } & $\mathrm{I}_{\mathrm{a}}$ & $\mathrm{I}_{\mathrm{b}}$ & $\mathrm{I}_{\mathrm{c}}$ & $\mathrm{V}_{\mathrm{a}}$ & $\mathrm{V}_{\mathrm{b}}$ & $\mathrm{V}_{\mathrm{c}}$ \\
\hline $\begin{array}{c}\text { Without } \\
\text { shunt } \\
\text { active filter }\end{array}$ & $\begin{array}{c}16.9 \\
9\end{array}$ & 18.03 & $\begin{array}{c}17.8 \\
6\end{array}$ & $\begin{array}{c}25.3 \\
1\end{array}$ & $\begin{array}{c}25.9 \\
0\end{array}$ & $\begin{array}{c}25.2 \\
2\end{array}$ \\
\hline $\begin{array}{c}\text { With shunt } \\
\text { active filter }\end{array}$ & 2.95 & 2.89 & 2.72 & 4.84 & 4.79 & 4.74 \\
\hline
\end{tabular}
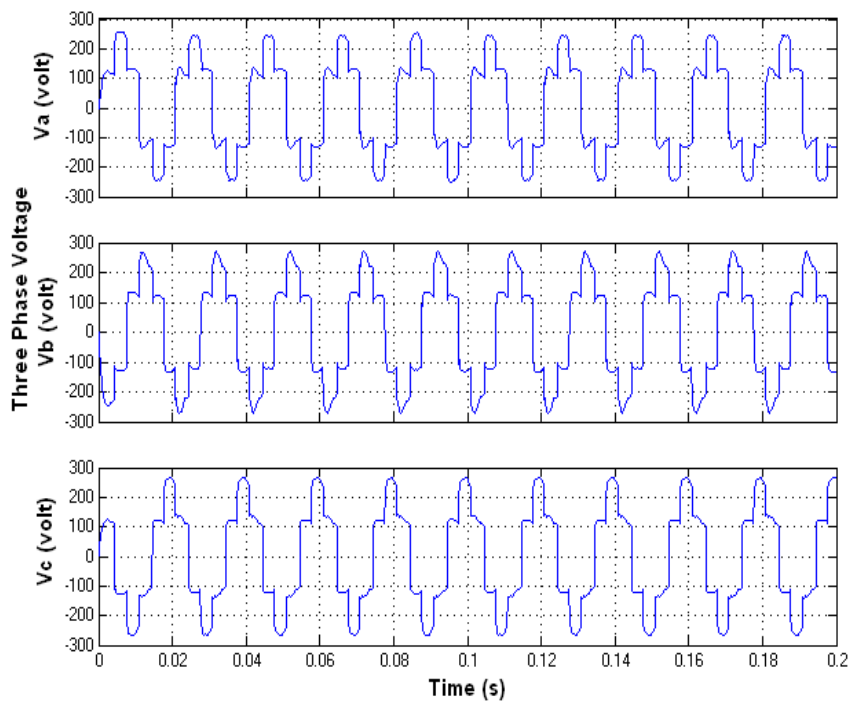

Fig.5. Three phase voltages of distribution system without shunt active filter. 


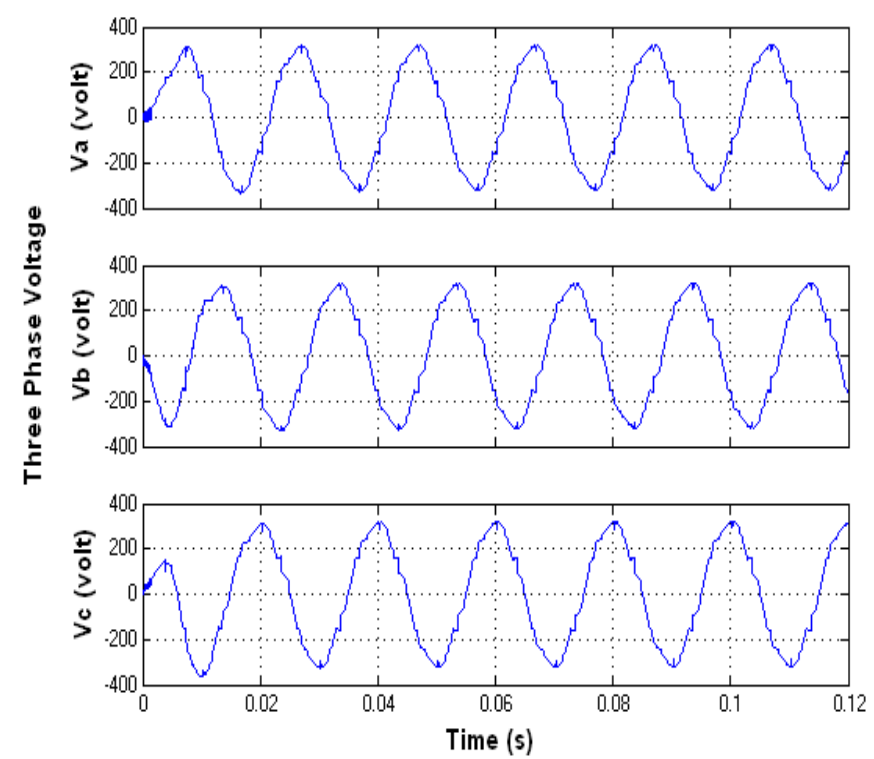

Fig.6. Three phase voltages of distribution system with shunt active filter.

Fig. 7 show the three phases source current of distribution system without shunt active filter. It can be seen that wave shapes are non sinusoidal (the harmonic is affected in the source currents). Fig. 8 show the three phases source current of distribution system with shunt active filter. It can be seen that wave shapes are almost nearly sinusoidal (the harmonic is suppressed in the source currents).

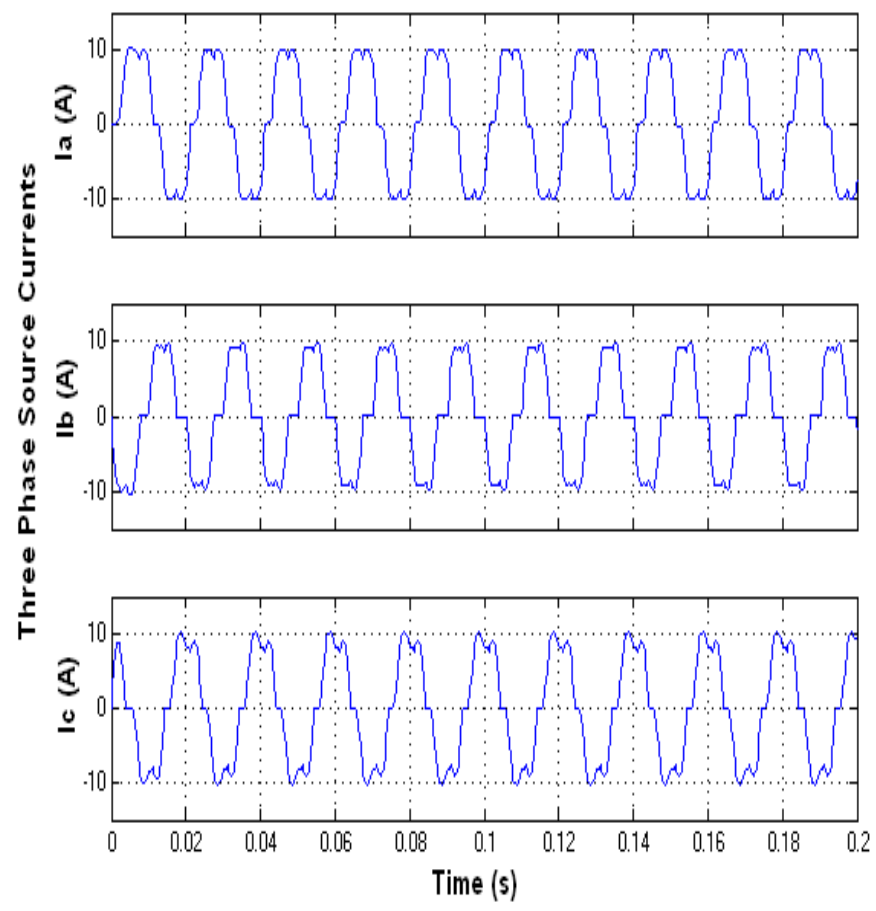

Fig. 7. Three phase source currents of distribution system without shunt active filter.

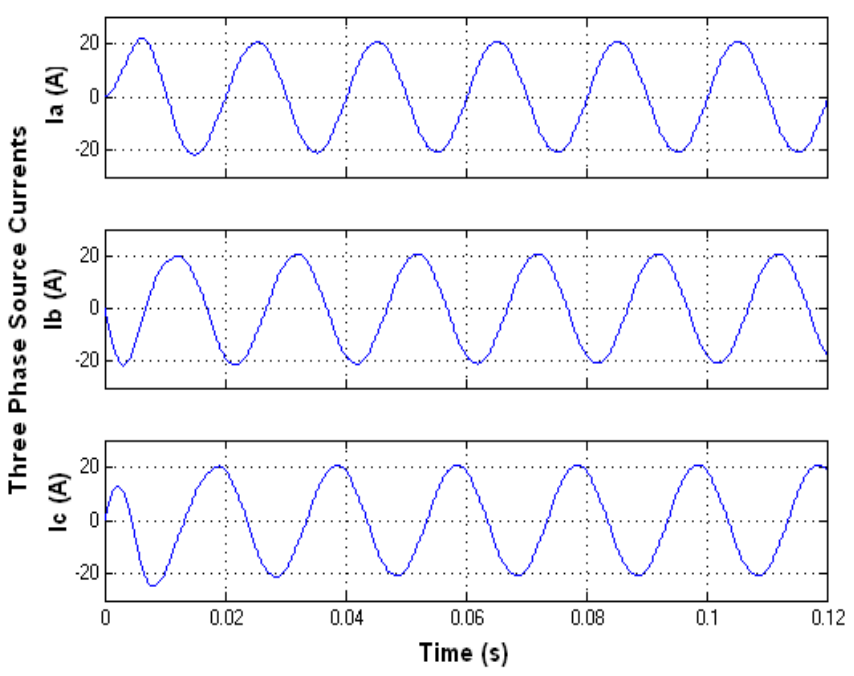

Fig. 8. Three phase source current of distribution system with shunt active filter.
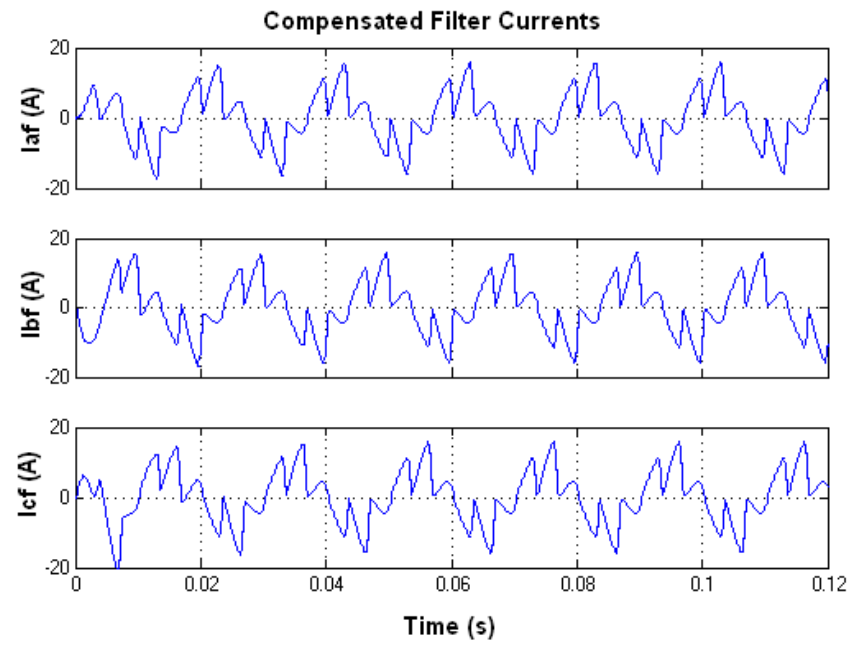

Fig. 9. Compensating currents with shunt active filter.

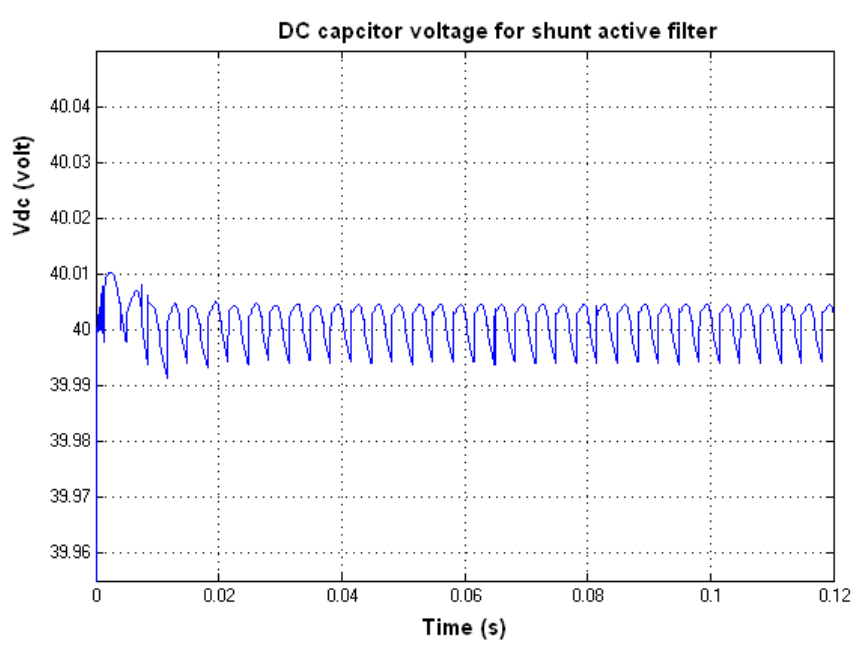

Fig.10. DC voltage of shunt active filter. 
Fig. 9 show the three phases compensated currents for shunt active filter. In Fig. 10 shows the constant and small ripple dc capacitor voltage of shunt active filter without startup-transient overshoot.

\section{CONCLUSIONS}

This paper has dealt with a shunt active filter for installation on a power distribution system, with focus on harmonic damping and voltage regulation performance. Harmonics present in the distribution system is significantly reduced by shunt active filter. It has been successfully demonstrated in Matlab/Simulink. Simulated results were showed good dc bus voltage - regulation, reduced source harmonic currents and have stable operation. The main disadvantage of this $\mathrm{P}-\mathrm{Q}$ theory is selective harmonics cannot be damped.

\section{REFERENCES}

[1] H.Akagi, 1997. Control strategy and site selection of a shunt active filter for damping of harmonic propagation in power distribution systems, IEEE Trans. Power Delivery, vol. 12, no. 1, pp. 354-363, Feb.1997.

[2] Y.Sato, T.Kawase, M.Akiyama, and T.Kataoka, 2000. A control strategy for general - purpose active filters based on voltage detection, IEEE Trans. Ind. Appl., vol. 36, no.5, pp.1405-1412, Sep / Oct.2000.

[3] D.Detjen, L.Jacobs, R.W.DeDoncker, and H.G.Mall, 2001. A new hybrid filter to damp resonances and compensate harmonic currents in industrial power systems with power factor correction equipment, IEEE Trans. Power Electron. vol.16, no. 6, pp. 821-827, Nov.2001.
[4] P.Jintakosonwit, H.Fujita, and H.Akagi, 2002. Control and performance of a fully - digital - controlled shunt active filter for installation on a power distribution system, IEEE Trans. Power Electron., vol.17, no.1, pp.132-140, Jan.2002.

[5] H.Akagi and H.Fujita, 2007. Voltage - Regulation Performance of a Shunt Active Filter Intended for Installation on a Power Distribution System, IEEE transactions on power electronics, vol.22, no.3, (May 2007).

[6] R.Inzunza and H.Akagi, 2005. A $6.6-\mathrm{kV}$ transformer less shunt hybrid active filter for installation on a power distribution system, IEEE Trans. Power Electron., vol.20, no.4, pp.893-900, Jul.2005.

[7] G.F.Reed, J.E.Greaf, T.Matsumoto, Y.Yonehata, M.Takeda, T.Aritsuka, Y.Hamasaki, F.Ojima, A.P.Sidell, R.E.Chervus, and C.K.Nebecker, 2000. Application of a 5 MVA, 4.16kV DSTATCOM system for voltage flicker compensation at seattle iron and metals, in Proc. IEEE Power Eng. Soc. Summer Meeting, 2000, vol.3, pp.1605-1611.

[8] P.S.Sensarma, K.R.Padiyar, and V.Ramanarayanan, 2001 Analysis and performance evaluation of a distribution STATCOM for compensating voltage fluctuations, IEEE Trans. Power Delivery, vol.16, no.2, pp.259-264, May2001. 